\title{
ESENSI TASAWUF AKHLAKI DI ERA MODERNISASI
}

\author{
Audah Mannan \\ Fakultas Dakawah \& Komunikasi \\ UIN Alauddin Makassar \\ E-mail: audah.mannan@uin-alauddin.ac.id
}

\begin{abstract}
Abstrak
Tasawuf sebagai salah satu tipe mistisisme, dalam bahasa Inggris disebut sufisme. Kata tasawuf mulai dipercakapkan pada akhir abad kedua hijriah yang dikaitkan dengan salah satu jenis pakaian kasar yang disebut shuff atau wol kasar. Tasawuf memiliki obsesi kedamaian dan kebahagiaan spiritual yang abadi. Tasawuf berfungsi sebagai pengendali berbagai kekuatan yang bersifat merusak keseimbangan daya dan jiwa, agar ia kebal terhadap pengaruh luar dirinya untuk mencapai kedamaian dan kebahagiaan jiwa.

Esensi agama Islam adalah akhlak, yaitu akhlak antara seorang hamba dengan Tuhannya, antara seorang dengan dirinya sendiri, antara dia dengan orang lain, termasuk anggota masyarakat dengan lingkungannya. Akhlak yang terjalin dalam hubungan antar hamba dengan Tuhan menegasikan berbagai akhlak yang buruk, seperti tamak, rakus, gila harta, menindas, mengabdikan diri kepada selain khaliq, membiarkan orang yang lemah dan berkianat. Sebaliknya, mengedepankan akhlak kebajikan (terpuji) bisa menambah kesempurnaan iman seseorang, karena seorang mukmin yang sempurna adalah mereka yang paling sempurna akhlaknya

Akibat modernisasi dan industrialisasi, manusia mengalami degradasi akhlak yang dapat menjatuhkan harkat dan martabatnya. Kehidupan modern seperti sekarang ini sering menampilkan sifat-sifat yang tidak terpuji, terutama dalam menghadapi materi yang gemerlap ini. Sifat-sifat yang tidak terpuji tersebut adalah hirsh, yaitu keinginan yang berlebih-lebihan terhadapa materi. Cara menghilangkan sifat-sifat tersebut ialah dengan mengadakan penghayatan atas keimanan dan ibadahnya, mengadakan latihan secara bersungguh-sungguh, berusaha merubah sifat-sifatnya itu Agar posisi seseorang berbalik, yakni hawa nafsunya dikuasai oleh akal yang telah mendapat bimbingan wahyu, dalam dunia tasawuf diajarkan berbagai cara, seperti riyadhah (latihan) dan mujahadah (bersungguh-sungguh) dalam melawan hawa nafsu tadi. Dengan jalan ini diharapkan seseorang mendapatkan jalan yang diridlai Allah swt. Esensi dari tasawuf akhlaki dalam kehidupan masyarakat modern memiliki fungsi yaitu sebagai pendidikan Spiritual, pendidikan Kepribadian, pendidikan Sosial.
\end{abstract}

Keywords:

Tasawuf, Aakhlak, Modernisasi

\section{PENDAHULUAN}

Tasawuf jika ditelaah secara mendalam, sebenarnya memiliki aspek-aspek strategis yang potensial dalam segala sendi kehidupan manusia, tetapi esensi tersebut akan sia-sia apabila umat Islam sendiri tidak mampu memanfaatkan "essence of values" dari tasawuf dengan sebaik-baiknya. Pada garis besarnya, tasawuf mempunyai peranan dan fungsi yang vital dalam pengembangan hidup manusia dengan segala amalanamalan yang ada. Hal ini disebabkan karena umat manusia bukan hanya membutuhkan pemenuhan kebutuhan materi saja, tetapi juga memerlukan kebutuhan batin. 
Nasib agama Islam di zaman modern ini juga sangat ditentukan oleh sejauh mana kemampuan umat Islam merespons secara tepat tuntutan dan perubahan sejarah yang terjadi di era modern. Sebagaimana pendapat Dadang Kahmad, bahwa fenomena munculnya tasawuf pada zaman modern ini merupakan salah satu usaha reinterpretasi dan reaktualisasi tertentu kepada ajaran agama Islam, dengan tujuan agar tidak saja menjadi relevan bagi kehidupan modern, tetapi juga untuk mengefektifkan fungsinya sebagai "sumber makna hidup" bagi pemeluknya. ${ }^{1}$

Di tengah-tengah situasi masyarakat yang cenderung mengarah kepada dekadensi akhlak seperti yang gejala-gejalanya mulai nampak saat ini dan akibat negatifnya mulai terasa dalam kehidupan, masalah tasawuf mulai mendapatkan perhatian dan dituntut peranannya untuk terlibat secara aktif mengatasi masalahmasalah tersebut. Terjadinya kebakaran hutan dengan segala akibatnya yang merugikan, praktek pengguguran kandungan (aborsi), pemerkosaan, pembunuhan, penipuan, penyalahgunaan obat-obat terlarang, pergaulan bebas yang mengarah pada perilaku penyimpangan seksual, penimbunan harta kekayaan dengan dampaknya yang menjurus pada kesenjangan sosial, disia-siakannya masalah keadilan dan lain sebagainya adalah bermula dari kekotoran jiwa manusia, yaitu jiwa yang jauh dari bimbingan Tuhan, yang disebabkan ia tidak pernah mencoba mendekati-Nya.

Untuk mengatasi masalah ini tasawuf yang memiliki potensi dan otoritas, karena di dalam tasawuf dibina secara intensif tentang cara-cara agar seseorang senantiasa merasakan kehadiran Tuhan dalam dirinya. Dengan cara demikian. Ia akan malu berbuat menyimpang, karena merasa diperhatikan oleh Tuhan. ${ }^{2}$

Mengimplementasikan ajaran-ajaran tasawuf, maka manusia akan sadar bahwa semua yang ada di dunia ini (termasuk eksistensi ilmu pengetahuan dan teknologi modern) tidak lain adalah milik Allah. Dengan demikian, maka eksistensi modernisasi harus dimanfaatkan dalam batas-batas kepentingan Ilahiyah yakni digunakan sebesarbesarnya untuk kepentingan manusia, bukan justru sebaliknya, membuat kerusakan di dunia. Modernisasi dapat mengantarkan manusia ke tingkat religiusitas yang agung, yakni pencarian terus menerus bentuk-bentuk baru, baik lewat usaha kreatif maupun kemampuan penalaran. Kreatifitas tersebut menganjurkan manusia untuk memikirkan masalah modernisasi dan terus meningkatkannya.

Dari latar belakang tersebut, yang menjadi topik bahasan dalam tulisan ini adalah bagaimana Esensi dari tasawuf akhlaki di era Medoernisasi.

\section{MAKNA DAN ESENSI TASAWUF}

\section{Makna Tasawuf}

Membuat suatu rumusan tentang definisi dan batasan yang tepat berkaitan dengan pengertian tasawuf adalah hal yang tidak mudah, hal ini telah diakui oleh para

\footnotetext{
${ }^{1}$ Dadang Kahmad, Tarekat dalam Islam: Spiritualitas Masyarakat Modern, (Bandung: Pustaka Setia, 2002), h. 70

${ }^{2}$ Abuddin Nata, Metodologi Studi Islam (Jakarta: Raja Grafindo Persada, 2000), h. 279
} 
ahli tasawuf. Keadaan demikian disebabkan oleh kecenderungan spiritual pada setiap pemahaman agama, aliran filsafat, dan peradaban dalam berbagai kurun waktu. ${ }^{3}$ Oleh karena itu, wajar apabila setiap orang menyatakan pengalaman pribadinya dalam konteks pemikiran dan kepercayaan yang berkembang pada masyarakatnya. ${ }^{4} \mathrm{Di}$ samping itu, karena tasawuf adalah aspek esoteris yang menekankan unsur batin yang sangat tergantung pada pengalaman spiritual masing-masing pelaku individu, sehingga memang wajar bila pengertian tasawuf yang muncul di kalangan para sufi seringkali ditemukan perbedaan-perbedaan. ${ }^{5}$ Begitu juga pemahaman terhadap pengertian tasawuf yang dipersepsikan oleh Gus Dur.

S. H. Nasr menyatakan bahwa tasawuf pada hakekatnya adalah dimensi terdalam dan esoteris dari Islam ( the inner and esoteric dimension of Islam ) yang bersumber dari al-Qur'an dan al-Hadis. Adapun syari'ah adalah dimensi luar atau eksoteris ajaran Islam. Pengamalan kedua dimensi itu secara seimbang merupakan keharusan dari setiap muslim, agar di dalam mendekatkan diri kepada Allah menjadi sempurna lahir dan batin $^{6}$. Sementara itu Ibn Khaldun menyatakan bahwa tasawuf termasuk salah satu ilmu agama yang baru dalam Islam. Cikal bakalnya bermula dari generasi pertama umat Islam, baik dari kalangan sahabat, tabi'in, maupun generasi setelahnya. Ia adalah jalan kebenaran dan petunjuk yang asal usulnya adalah pemusatan diri dalam ibadah, pengharapan diri sepenuhnya kepada Allah, penjauhan diri dari kemaksiatan, serta pemisahan diri dari orang lain untuk berkhalwat dan beribadah ${ }^{7}$.

\section{a. Etimologi Tasawuf}

Nomenklatur kata tasawuf meskipun tidak disebutkan secara eksplisit dalam alQur'an dan al-Sunnah,bukan berarti diharamkan penggunaan nama itu. Namun demikian tasawuf sendiri belum pernah ada pada zaman Rasulullah Saw.tetapi sisi esensial dari tasawuf itu sudah benar-benar mengemuka pada waktu itu.Tasawuf disatu sisi juga merupakan sebuah cabang ilmu yang berbanding lurus dengan cabang-cabang ilmu lain dalam khazanah peradaban Islam, seperti: Fiqh, Nahwu, Mantiq, dan Balaghah. Kalau fikih fungsinya untuk menghukumi perkara-perkara dhahir, maka fungsi tasawuf adalah untuk menseterilkan hati manusia dari berbagai macam penyakit hati dan untuk mengantarkan manusia menuju keselamatan dunia dan akhirat. ${ }^{8}$

Harun Nasution mengemukakan tentang teori etimologi kata sufi sebagai berikut:

\footnotetext{
${ }^{3}$ At-Taftazani, dalam Syamsun Ni'am, The Wisdom Of KH Achmad Siddiq: Membumikan Tasawuf (Surabaya: Erlangga, 2006), h. 99.

${ }^{4}$ Alwi Shihab, Islam Sufistik: "Islam Pertama" dan Pengaruhnya hingga Kini di Indonesia (Bandung: Mizan, 2001), h. 27.

${ }^{5}$ Syamsun Ni'am, The Wisdom Of KH Achmad Siddiq: Membumikan Tasawuf (Surabaya: Erlangga, 2006), h. 99-100.

${ }^{6}$ Sayyid Husein Nasr, Three Muslem Sages (Cambridge: Havard University Press, 1969), 36

${ }^{7}$ Ibn Khaldun, al-Muqaddimah (Kairo: al-Matba'ah al-Bahiyah, t.t.), h.370

${ }^{8}$ Yusuf Khathar Muhammad, al-Mausu'ah al-Yusufiyah fî bayâni adillah al-Sufiyah, Dar elTaqwâ, Damascus,tt., hal.9.
} 
1) Ahl al-suffah ( الصفة أهل ), yaitu orang-orang yang ikut pindah dengan Nabi Muhammmad dari Mekah ke Madinah. Kepindahan mereka mengakibatkan kehilangan harta, sehingga mereka secara ekonomi menjadi miskin. Mereka tinggal di masjid Nabi dan tidur di atas bangku batu dengan memakai pelana sebagai bantal. Pelana tersebut dikenal dengan istilah suffah. Mereka meskipun miskin, tetapi berhati baik dan mulia. Keadaan yang melekat pada dirinya adalah tidak mementingkan keduniaan dan miskin.

2) Saf (صف pertama. Istilah ini diambil dari keutamaan dan kemuliaan orang yang salat di saf pertama.

3) Sufi dari kata safa (صفي) dan sofia yang artinya suci. Seorang sufi adalah orang yang disucikan. Mereka juga orang yang telah mensucikan dirinya melalui latihan berat dan lama.

4) Suf ( صوف), kain yang dibuat dari bulu, yaitu wol. Namun kain wol yang dipakai kaum sufi adalah wol kasar dan bukan wol halus seperti sekarang. Wol kasar yang dipakai pada waktu itu adalah simbol kesederhanaan dan kemiskinan. Lawannya adalah memakai sutra sebagai simbol kemewahan sebagaimana perilaku kalangan pemerintahan. ${ }^{9}$

Pengertian tasawuf pada umumnya cenderung dimaknai dengan usaha untuk mendekatkan diri kepada Tuhan dengan sedekat mungkin melalui metode pensucian rohani maupun dengan memperbanyak amalan ibadah, metode pensucian diri dengan dzikir dan amalan itulah yang di istilahkan dengan thoriqoh atau tarikat yang di laksanakan oleh para murid tasawuf dengan mengikuti bimbingan dari sang mursyid atau syeikh sufi 10 .

Tasawuf lebih menekankan spiritualitas dalam berbagai aspek oleh karena itu para ahli tasawuf, yang disebut sufi, mempercayai keutamaan spirit ketimbang jasad, mempercayai dunia spiritual ketimbang dunia material. Bertolak dari keyakinan ini, maka muncullah cara hidup spiritual. Istilah tasawuf yang berasal dari kata shafa yang artinya kesucian, dengan artian mensucikan diri dari kotoran-kotoran atau pengaruhpengaruh jasmani dalam rangka mendekatkan diri kepada Allah Yang Maha Suci. ${ }^{11}$

Dengan demikian, tasawuf justeru mengaitkan kehidupan individu dengan masyarakatnya, sehingga bermakna positif bukan negatif ${ }^{12}$. Namun para ahli tetap berupaya merumuskan definisi "tasawuf" yang didasarkan pada satu asas yang disepakati, yaitu moralitas yang berdasarkan Islam.

\section{b. Terminologi Tasawuf}

Pencarian akar kata tasawuf sebagai upaya awal untuk mendefinisikan tasawuf ternyata sulit untuk menarik suatu kesimpulan. Hal itu berpangkal pada esensi tasawuf

\footnotetext{
${ }^{9}$ Harun Nasution, Falsafah dan Mistisisme dalam Islam (Jakarta: Bulan Bintang, 1990), h.57-58

${ }^{10}$ Pengantar Ilmu Tasawuf (Sumatra Utara: Proyek Pembinaan Perguruan Tinggi Agama, Institut Agama Islam Negri, 1981/1982), h. 273-274.

${ }^{11}$ Mulyadi Kartanegara, Menyelami lubuk Tasawuf (Jakarta: Erlangga, 2006), h.2-4

${ }^{12}$ At-Taftazani, dalam Syamsun Ni'am, The Wisdom Of KH Achmad Siddiq: Membumikan
} Tasawu, h, 7 
sebagai pengalaman rohani yang hampir tidak mungkin dijelaskan secara tepat melalui bahasa lisan, masing-masing orang berbeda-beda pengalaman dan penghayatannya sehingga pengungkapannya juga berbeda. Maka muncullah definisi tasawuf sebanyak orang yang mencoba menginformasikan pengalaman rohaniahnya.

1) Junaid al-Baghdadi mengatakan tasawuf adalah membersihkan hati dari apa yang mengganggu perasaan kebanyakan makhluk, berjuang menanggalkan budi, memadamkan sifat-sifat kelemahan kita sebagai manusia, menjauhi segala seruan dari hawa nafsu, menghendaki sifat-sifat suci keruhanian, dan bergantung pada ilmu-ilmu haqiqat, memakai barang yang terlebih penting dan terlebih kekal, menaburkan nasihat kepada sesama umat, memegang teguh janji dengan Allah dalam segala haqiqat, dan mengikuti contoh Rasulullah dalam segala syari'at. ${ }^{13}$

2) Dzun Nun al-Misri, berpendapat bahwa sufi adalah orang yang didalam hidupnya tidak disusahkan dengan permintaan dan tidak pula dicemaskan dengan terampasnya barang. Selanjutnya al-Misri juga mengatakan bahwa mereka itu merupakan komonitas yang mendahulukan Allah di atas segalanya, sehingga Allah pun mendahulukan mereka di atas segalanya. ${ }^{14}$

3) Ibrahim Basyuni sarjana muslim berkebangsaan Mesir mengategorikan pengertian tasawuf pada tiga hal: ${ }^{15}$

\section{a) Al Bidayah}

Al-bidayat, yaitu prinsip awal tumbuhnya tasawuf sebagai manifestasi dari kesadaran spiritual manusia tentang dirinya sebagai makhluk Tuhan, sehingga mendorong para sufi untuk memusatkan perhatiannya dalam beribadah kepada khaliqnya, yang dibarengi dengan kehidupan asketisme ( zuhud) dengan tujuan utama pembinaan moral. Berangkat dari prinsip al-bidayat di atas, tasawuf didefinisikan sebagai upaya memahami hakekat Allah, seraya melupakan kehidupan duniawi. Definisi lain mengatakan, bahwa tasawuf adalah usaha mengisi hati dengan selalu mengingat kepada Allah yang merupakan landasan lahirnya ajaran hubb ( cinta ilahi).

Kelompok ini merasakan fitrahnya bahwa yang wujud itu tidak terbatas pada sesuatu yang terlihat saja. Di balik yang terlihat, ternyata masih ada wujud yang lebih sempurna yang selalu dirindukan oleh ruh manusia. Yaitu Allah, Tuhan semesta alam. Tabir yang memisahkan antara manusia dengan wujud yang sempurna itu sedikit demi sedikit akan hilang jika seseorang sering bertafakur dan mengenal dirinya serta mengurangi keinginan nafsu jasmaninya. Tabir pemisah itu akan terkuak jika hati

\footnotetext{
${ }^{13}$ Hamka, Perkembangan Tasawuf dari Abad ke Abad (Cet. IV; 1906), h. 78., dalam M Zain Abdullah, Dzikir dan Tasawuf (Solo: Qaula, 2007), h. 11-12.

${ }^{14}$ Abu Nasr al-Sarraj al-Tusi, Al-Luma' (Mesir: Dar al- Kutub al-Hadithah, 1960), h.45-46.

${ }^{15}$ Yunasril Ali, Ensiklopedi Tematis: Dunia Islam, Jil. IV.,Taufik Abdullah dkk. (ed.), (Jakarta: Ichtiar Baru Van Hoeve, 2002), h. 140. Lihat juga Amin Syukur, Menggugat Tasawuf: Sufisme dan Tanggung Jawab Sosial Abad 21 (Yogyakarta:Pustaka pelajar, 1999), h.11-16.
} 
seseorang akan penuh dengan limpahan cahaya atau nur yang akan membangkitkan perasaan dan kesungguhan serta membawanya kepada ketenangan jiwa yang sempurna.

Ma'ruf al Kharki (W. 200 H),yang mendefinisikan Al Bidayah adalah upaya mengambil hakikat dari kehidupan dan putus asa terhadap apa yang ada di tangan makhluk, sedangkan Abu Turab al-Nakhsabi (W. 245 H). berpendapat bahwa sufi sejati tidak akan terkotori oleh apapun, justru dia akan membersihkan sesuatu. ${ }^{16}$

\section{b) Al Mujahadat}

Setiap manusia diamanahkan oleh Allah swt untuk berjuang di jalan-Nya. Maksud jihad disini adalah proses berjuang tadi. Sebenarnya berjuang bukan berarti berperang saja. Tetapi melaksanakan amar ma'aruf nahi munkar sudah merupakan perjuangan. Amalan untuk membersihkan rohani hendaklah berlandaskan syariat, tidak ada pengecualian. Tanpa syariat, tasawuf tidak akan bermakna. Contohnya, orang yang baik perilaku atau jiwanya yang suka bersedekah dan sebagainya tetapi tidak melaksanakan shalat, zakat, puasa dan menunaikan haji, maka ia bukanlah merupakan seorang muslim dalam arti yang sebenarnya. Ada juga orang yang mengaku pengamal tasawuf atau sufi tetapi menyatakan tidak perlu shalat, zakat, puasa dan sebagainya yang ditetapkan oleh syariat. Orang seperti ini akan berbahaya karena ia sudah sesat dan boleh jadi dia akan menyesatkan orang lain.

Sufi kelompok ini mencoba menghiasi diri dengan sesuatu perbuatan yang diingini oleh agama dan kebiasaan yang mulia. Ada dua orang tokoh dari kelompok ini, Abu Muhammad al-Jariri, yang mengatakan bahwa tasawuf adalah memasuki suatu akhlak sunni dan keluar dari semua makhluk rendah, dan Samnun al Muhib: yang mengatakan tasawuf adalah suatu keyakinan bahwa "Engkau tidak memiliki sesuatu dan tidak dimiliki sesuatu". ${ }^{17}$ Dengan demikian tasawuf, adalah ilmu yang mengajarkan sifat manusia dari sifat-sifat tercela agar menjadi baik dan luhur, sehingga hatinya menjadi benar dan lurus dalam menuju ke jalan Allah swt.

\section{c) Al Mudzaqah}

Al Mudzaqah adalah hasil yang diharapkan dari mengamalkan tasawuf. Kehidupan tasawuf menurut kelompok ini adalah segala kemauan ditundukkan untuk melarut dalam kehendak Tuhan dengan jalan rindu (al isyq) dan intuisi (al wajd). Segala umur, kegiatan, hati semuanya dikerahkan sehingga hubungannya dengan Allah terasa lebih kuat dan bersih. Tokoh yang mendeskripsikan kelompok ini adalah Abu Husain al-Muzyu, yang mengatakan tasawuf adalah berserah diri secara bulat kepada al Haq. Sedangkan al Junaid, mengatakan tasawuf adalah sikap seseorang yang merasa selalu

\footnotetext{
${ }^{16}$ Solihin dan Rosyid Anwar, Akhlak Tasawuf, Manusia, Etika, dan Makna Hidup (Cet. I; Bandung: Nuansa, 2005), h.152

${ }^{17}$ Solihin dan Rosyid Anwar, Akhlak Tasawuf, Manusia, Etika, dan Makna Hidup, h.153
} 
bersama Allah tanpa penghubung. Tasawuf adalah keluar dari pekerti yang tercela dan masuk kepada budi pekerti yang terpuji. ${ }^{18}$

Ketiga definisi di atas jika dihubungkan satu dengan yang lain, maka tasawuf pada intinya adalah upaya untuk melatih jiwa dengan berbagai kegiatan yang dapat membebaskan seseorang dari pengaruh kehidupan dunia sehingga dia dapat dekat dengan Allah.

Berdasarkan kajian terhadap tasawuf dari berbagai alirannya, ternyata tasawuf memiliki lima ciri khas atau karakteristik yaitu: Pertama: bahwa semua aliran tasawuf memiliki obsesi kedamaian dan kebahagiaan spiritual yang abadi. Tasawuf berfungsi sebagai pengendali berbagai kekuatan yang merusak keseimbangan daya dan getaran jiwa sehingga ia bebas dari pengaruh di luar hakikat dirinya. Kedua: Tasawuf semacam pengetahuan langsung yang didapat melalui tanggapan intuisi. Bahwa mencari hakikat kebenaran melalui penyingkapan tabir penghalang yang mengantarai sufi dengan realitas itu. Dengan terbukanya tirai penghalang maka sufi dapat melihat langsung dan merasakan realitas itu. Ketiga: Bahwa untuk meningkatkan kualitas moral yakni pemurnian jiwa melalui serial latihan yang keras dan berkelanjutan. Keempat: peleburan diri dengan sifat-sifat Tuhan atau penyatuan diri dengan-Nya dalam realitas yang tunggal. Kelima: pengungkapan pengalaman yang digunakan selalu memuat makna ganda, tetapi yang dimaksudkan biasanya adalah makna apa yang ia rasa dan alami bukan arti harfiahnya, disebut sathohat (perasaan yang meluap). ${ }^{19}$

Dengan kata lain dapat dinyatakan bahwa esensi tasawuf terletak pada pengejawantahan dari ajaran tentang Ihsan, salah satu dari tiga serangkai dari ajaran Islam yaitu Islam itu sendiri, Iman dan Ihsan. Esoterisme sufi adalah perwujudan dari sabda Nabi sendiri, bahwa Ihsan adalah keadaan dimana ketika kita menyembah Allah seolah-olah kita melihat-Nya dan kalupun kita tidak melihat-Nya, maka Dia yang melihat kita. Apa yang diajarkan tasawuf tidak lain adalah bagaimana menyembah Allah dengan suatu kesadaran penuh bahwa kita berada di dekat-Nya, sehingga kita "melihat"-Nya atau bahwa Dia senantiasa mengawasi kita dan kita senantiasa berdiri di hadapan-Nya.

\section{Akhlak dan Modernisasi}

Esensi agama Islam adalah akhlak, yaitu akhlak antara seorang hamba dengan Tuhannya, antara seorang dengan dirinya sendiri, antara dia dengan orang lain, termasuk anggota masyarakat dengan lingkungannya. Akhlak yang terjalin dalam hubungan antar hamba dengan Tuhan menegasikan berbagai akhlak yang buruk, seperti tamak, rakus, gila harta, menindas, mengabdikan diri kepada selain khaliq, membiarkan orang yang lemah dan berkianat. Namun sebaliknya, mengedepankan akhlak kebajikan (terpuji) bisa menambah kesempurnaan iman seseorang, karena seorang mukmin yang sempurna adalah mereka yang paling sempurna akhlaknya. Dalam agama Islam hal

\footnotetext{
${ }^{18}$ Solihin dan Rosyid Anwar, Akhlak Tasawuf, Manusia, Etika, dan Makna Hidup, h.153

${ }^{19}$ A. Rivay Siregar, Tasawuf : Dari Sufisme Klasik ke Neo-Sufisme, h 35-36
} 
tersebut bisa dicapai, setelah seseorang beriman-percaya pada rukun Iman dan juga menjalankan syariat Islam sebagaimana dalam rukun Islam. Jadi tiga komponen utama dari ajaran Islam, yakni Iman, Islam dan Ihsan harus seiring dan sejalan dalam kehidupan seorang muslim.

Akhlak seseorang dengan sendirinya melahirkan tindakan positif bagi dirinya, seperti menjaga kesehatan jiwa dan raga, menjaga fitrah dan memenuhi kebutuhankebutuhan ruh dan jasmani. Dengan demikian, krisis spiritual tidak akan terjadi padanya. Selanjutnya akhlak yang terjalin pada hubungan antara seorang dengan orang lain, menyebabkan keharmonisan, kedamaian dan keselarasan dalam hidup yang dapat mencegah, mengobati berbagai krisis (spiritual, akhlak dan budaya).

Tercerabutnya akar spiritualitas dari panggung kehidupan, salah satunya disebabkan oleh pola hidup global yang serba dilayani perangkat teknologi yang serba otomat. Kondisi seperti ini kemudian menimbulkan berbagai kritik dan usaha pencarian paradigma baru yang diharapkan membawa kesadaran untuk hidup bermakna. "Organized Religion"-yang dilihat sebelah mata hanya pada aspek formalnya-tidak selamanya dianggap dapat berikan terapi kehampaan dan kegersangan hidup. Dari kondisi ini, kemudian timbul gejala pencarian makna hidup dan pemenuhan diri yang sarat dengan spiritualitas. Upaya ini diharapkan dapat mengatasi derita alienasi manusia modern.

Umat manusia telah terbentuk, sebagaimana produk industri itu sendiri. Tak ada lagi keunikan; yang ada hanyalah kekakuan yang seragam sehingga secara sadar atau tidak sadar, manusia berangsur-angsur kehilangan asas kemerdekaannya. Padahal itulah yang dijadikan tumpuan ilmu pengetahuan dan teknologi. Itikad dikembangkannya ilmu pengetahuan dan teknologi sebagai pembebasan keterbatasan manusia, justru menghadirkan kerumitan hidup dan kegelapan ruang spiritual. Waktu yang berjalan telah dianggap terlampau cepat berlalu tanpa makna, tanpa membawa penyelesaian masalah hidup yang direncanakan.

Manusia terpacu oleh situasi mekanistis yang telah diciptakannya sendiri sehingga kehilangan waktu untuk merenungkan ayat-ayat Allah dan makna hidupnya. Manusia telah kehilangan kontak secara manusiawi dalam tata hubungan antar manusia karena manusia telah menjadi egoistis. Manusia kehilangan kontak dengan alam, sehingga menimbulkan kerusakan lingkungan menjadi masalah utama dama hidup modern. Manusia telah kehilangan orientasi, tidak tahu ke mana arah hidup tertuju. Di sinilah manusia telah kehilangan segala-galanya. ${ }^{20}$

Perjalanan umat manusia menuju masyarakat industrial seperti yang diuraikan terdahulu, proses yang menyertainya akan menimbulkan pergeseran nilai dan benturan budaya yang tidak dapat dielakkan karena memang budaya santai dari masyarakat agraris yang bertenaga hewani berlainan dengan budaya tepat waktu pada masyarakat industrial yang tenaganya serba mesin, dan nilai-nilai bergeser pada saat wanita, yang

\footnotetext{
${ }^{20}$ Dadang Kahmad, Sosiologi Agama (Bandung: Remaja Rosdakarya, 2000), h. 198
} 
semula sangat terikat dengan rumah dan keluarga, merasa bebas menggunakan kendaraan bermesin sebagai sarana transportasi dan pesawat telpon sebagai alat komunikasi. Dengan keimanan dan ketakwaan dapatlah dipilih nilai-nilai baru dan budaya baru yang sesuai dengan ajaran agama. ${ }^{21}$

Keterkaitan manusia modern kepada dunia spiritual, pada intinya ingin mencari keseimbangan baru dalam hidup. Kaum eksistensialisme, misalnya memandang manusia pada dasarnya ingin kembali pada kemerdekaannya yang telah tereduksi dalam kehidupan modern. Kehidupan modern dalam perspektif tersebut dapat dicapai apabila manusia senantiasa melakukan transformasi di segala bidang kehidupan.

\section{Tasawuf dan Akhlak}

Tasawuf berarti semangat Islam, sebab semua hukum Islam berdasarkan landasan akhlak. Dalam hal ini Hamka menyebutnya sebagai "tasawuf modern", yaitu "keluar dari budi pekerti yang tercela dan masuk kepada budi pekerti yang terpuji". Maksudnya adalah membersihkan jiwa, mendidik dan mempertinggi derajat budi, menekankan segala kelobaan dan kerakusan, memerangi syahwat yang berlebihan dari keperluan untuk kesentosaan diri. Kemudian tasawuf "akhlak" ini dari awalnya, dalam beberapa aspek utama, bahkan mengatur untuk mengikat doktrin al-Qur'an. Kenyataannya, untuk menyebutnya "akhlak" merupakan penyalahgunaan istilah. Akhlak menguasai hubungan intra-manusia dan akhlakitas al-Qur'an melakukan ini dengan sense of presence of God (rasa kehadiran Tuhan) yang kuat ${ }^{22}$

Doktrin sufi terhadap perasaan berdosa dan pengangkatan diri yang bersifat asketis membalikkan akhlakitas positif al-Qur'an ini ke dalam perjuangan melawan diri. Manusia dituntut bergulat dengan dirinya. Dimensi hubungan intra-manusia, yang merupakan inti dari akhlak al-Qur'an, secara praktis dihapus. Jika ini tidak terjadi, tasawuf akan menjadi aset spiritual Islam yang sangat positif. ${ }^{23}$ Sebenarnya dalam wacana intelektual pun ada satu konsep paham tasawuf yang tetap mempertahankan esensi awal dari tasawuf, yaitu akhlak. Itu sebabnya dapat disebut ' tasawuf akhlaki'. Perlu ditegaskan di sini, mengapa "akhlak" disebut esensi awal dari tasawuf, karena arahnya adalah melaksanakan hidup "sederhana" dan sikap hidup ini pada akhirnya membuahkan tindakan akhlak.

Esensi dari tasawuf akhlaki dalam kehidupan masyarakat modern memiliki fungsi sebagai berikut:

\section{Pendidikan Akhlak-Spiritual}

Kebangkitan spiritualitas terjadi di mana-mana, baik di Barat maupun dunia Islam. Di dunia Barat, kecenderungan untuk kembali pada spiritualitas ditandai dengan semakin merebaknya gerakan fundamentalisme agama dan kerohanian, terlepas dari

\footnotetext{
${ }^{21}$ Achmad Baiquni, Al-Qur'an; Ilmu Pengetahuan dan Teknologi (Yogyakarta: Dana Bhakti Prima Yasa, 1995), h. 154

${ }^{22}$ Hamka, Tasawuf Modern (Jakarta: Pustaka Panji Mas, 1996), h. 7.

${ }^{23}$ Fazlur Rahman, Gelombang Perubahan dalam Islam: Studi Fundamentalis Islam, terj. Aan Fahmia, (Jakarta: Raja Grafindo Persada, 2000), h. 154
} 
gerakan ini menimbulkan persoalan psikologis maupun sosiologis. Sementara di kalangan umat Islam ditandai dengan berbagai artikulasi keagamaan seperti fundamentalisme Islam, yang ekstrem dan menakutkan sampaipada bentuk artikulasi esoterik seperti akhir-akhir ini menggejala, yaitu gerakan sufisme (tasawuf).

Kebangkitan agama juga bisa ditandai dengan kebangkitan spiritual. Akibat proses modernisasi yang membawa dampak krisis batin manusia, maka orang cenderung mencari ketenangan dengan masuk ke dalam dunia sufi. Gejala bangkitnya sufisme itu bisa dilihat dalam hampir semua lapisan masyarakat muslim. Di negaranegara Barat, kelompok-kelompok tasawuf dan tarekat menjadi daya tarik orang memeluk Islam. Ketertarikan terhadap spiritualisme Islam itu bukan saja ditunjukkan oleh massa tetapi juga kalangan elit intelektual, seperti Sayyed Naquib Alatas, Sayyed Hossein Nasr, Martin Lings, Hamid Algar dan Mohammad Asad (Lepold Weiss). ${ }^{24}$

Masyarakat Barat kini bisa dijadikan contoh, mereka kini sedang meringkuk dalam penyakit jiwa. Penyakit akhlak yang penuh dengan dosa dan kerusuhan masyarakatnya yang materialistis di permukaan bumi penuh oleh kemarahan yang merupakan masyarakat celaka dan sengsara. ${ }^{25}$ Akan tetapi, pada kenyataannya, rasionalisme, materialisme, sekularisme, tidak menambah kebahagiaan hidup, justru menimbulkan dehumanisasi yang berakibat pada kegelisahan hidup. Lebih jauh, para ilmuwan menyebut era tercerabutnya nilai-nilai humanis sebagai the age anxiety (abad kecemasan). Gejalanya antara lain, munculnya krisis dalam setiap aspek kehidupan manusia. Mulai dari lingkungan akibat pencemaran industri, perubahan tata nilai, peperangan, lunturnya nilai-nilai tradisi dan penghayatan agama sebagai efek sampaing teknologi dan industri-modernisasi, serta munculnya berbagai penyakit yang mengerikan dan sulit disembuhkan. Semua gejala tersebut menjadi momok bagi masyarakat modern.

Masyarakat modern dihantui akan kecemasan, kegelisahan, frustasi, depresi, kehilangan semangat hidup dan penyakit psikosomatis lainnya, khususnya di kota-kota besar. Di mana beban psikologis ini sudah begitu mewabah. Sehingga banyak orang modern menderita existensial vacuun (kehampaan hidup) yang diakibatkan oleh rasa hidup tak bermakna. ${ }^{26}$ Untuk menanggulangi penyakit tersebut banyak upaya yang mereka lakukan, antara lain, konsultasi dengan berbagai ahli; dokter, psikolog, psikiater dan sebagainya. Ada juga yang lari dari kenyataan dengan minum-minuman keras, mengkonsumsi obat-obat terlarang dan perilaku yang menyimpang dari norma-norma agama. Tetapi tak jarang pula, mereka kembali ke pangkuan agama, yang mereka wujudkan dengan mengikuti pengajian-pengajian dan menjalankan ajaran tasawuf. Tasawuf menjadi tempat berteduh bagi orang-orang modern. Tasawuf menawarkan

\footnotetext{
${ }^{24}$ Syafiq A. Mughni, Nilai-nilai Islam : Perumusan Ajaran dan Upaya Aktualisasi (Yogyakarta: Pustaka Pelajar, 2001), h. 258.

${ }^{25}$ Kahar Masyhur, Membina Akhlak dan Akhlak (Jakarta: Rineka Cipta, 1994), h. 136.

${ }^{26} \mathrm{Mu}$ 'allim, "Dari Kesadaran Spiritual ke Tasawuf Sosial, h. 6.
} 
kekayaan spiritual yang bernilai tinggi. Lantas tasawuf banyak diburu orang. Orangorang baru sadar akan urgensi pemenuhan spiritualitas.

Penjelasan tersebut, jelaslah bahwa tasawuf mempunyai arti penting bagi manusia modern, di mana tasawuf mengingatkan manusia bahwa dirinya bukanlah sebuah robot, melainkan makhluk jasmaniah dan ruhaniah. Keduanya tidak bisa dipisahkan, sebagai makhluk dualitas ini, manusia mempunyai potensi untuk berhubungan dengan dunia materi dan dunia spiritual. Meminjam istilah Jalaluddin Rahmat sebagaimana dikutip Sulaiman al-Kumayi, manusia adalah "radio dua band" yang mampu menangkap gelombang panjang dan gelombang pendek. Ia mampu menangkap hukum-hukum alam di balik gejala-gejala fisik yang diamatinya, tetapi ia juga mampu menyadap isyarat-isyarat gaib dari alamyang lebih luas. ${ }^{27}$

Tasawuf bukanlah spiritualitas yang sekedar menjadi tempat pengasingan diri. Ia berusaha menampilkan visi religius otentik yang mengarahkan diri untuk melampaui diri. Sebuah visi yang tepat dalam menafsirkan dunia yang melingkupi seluruh realitas di dalamnya. Sebuah komitmen yang lebih besar dari sekedar tujuan perkembangan pribadi dan spiritualitas-an sich. Sebuah obsesi yang lebih tinggi dari sekedar pemahaman hidup di dunia dan materi. Tasawuf merupakan bentuk ajaran Islam, banyak menjanjikan hasrat hidup manusia seutuhnya daripada janji-janji spiritualisme. Ia bukan hanya untuk memahami realitas alam, tetapi ia juga untuk memahami eksistensi dari tingkat yang paling rendah hingga yang paling tinggi, yaitu kehadiran Ilahiah. ${ }^{28}$ Fungsi tasawuf sebagai terapi krisis spiritual sebagai berikut:

a. Tasawuf secara psikologis, merupakan hasil dari berbagai pengalaman spiritual dan merupakan bentuk dari pengetahuan langsung mengenai realitas-realitas ketuhanan yang cenderung menjadi inovator dalam agama. Pengalaman keagamaan ini memberikan sugesti dan pemuasan (pemenuhan kebutuhan) yang luar biasa bagi pemeluk agama.

b. Kehadiran Tuhan dalam bentuk pengalaman mistis dapat menimbulkan keyakinan yang sangat kuat. Perasaan mistik mampu menjadi akhlak force bagi amal-amal shalih. Dan selanjutnya, amal shalih akan membuahkan pengalaman-penglaman mistis yang lain dengan lebih tinggi kualitasnya.

c. Dalam tasawuf, hubungan seorang dengan Allah dijalin atas rasa kecintaan. Allah bagi Sufi, bukanlah Dzat yang menakutkan, tetapi Dia adalah Dzat yang Sempurna, Indah, Penyayang dan Pengasih, Kekal, al-Haq, serta selalu hadir kapan pun dan dimana pun. Oleh karena itu, Dia adalah Dzat yang paling patut dicintai dan diabdi. Hubungan yang mesra ini akan mendorong seseorang untuk melakukan sesuatu yang baik, lebih baik bahkan yang terbaik. ${ }^{29}$

\footnotetext{
${ }^{27}$ Sulaiman Al-Kumayi, “Urban Sufism.........., h. 8.

${ }^{28}$ Ahmad Najib Burhani, .............. 166.

${ }^{29}$ Abdul Muhayya, "Peranan Tasawuf dalam Menanggulangi Krisis Spiritual", dalam M. Amin Syukur dan Abdul Muhayya', (eds.), Tasawuf dan Krisis, (Yogyakarta: Pustaka Pelajar, 2001), h. 26.
} 
Hubungan tersebut dapat menjadi alat kontrol atas penyimpangan dari berbagai perbuatan yang tercela. Melakukan akhlak yang tidak terpuji berarti menodai dan mengkhianati makna mahabbah yang telah terjalin. Akhlak yang menjadi inti dari ajaran tasawuf yang dapat mendorong manusia untuk memelihara dirinya dari meninggalkan kebutuhan-kebutuhan spiritualitasnya. Tasawuf mempunyai potensi besar yang mampu menawarkan pembebasan spiritual, mengajak manusia mengenal dirinya dan mengenal Tuhannya. Tasawuf menjadi penuntun hidup berakhlak, sehingga dapat menunjukkan eksistensi manusia sebagai makhluk termulia di muka bumi ini (ahsani taqwiim).

\section{Pendidikan Akhlak- Kepribadian}

Tujuan tasawuf adalah untuk akhlak elaboration perfection, kesempurnaan etika. Tanpa kesempurnaan etika manusia tidak bisa maju lebih jauh lagi. Salah satu landasan tasawuf adalah kesempurnaan etika, dalam sejarah tasawuf bahwa tujuan tasawuf ini pada dasarnya merupakan etika Islam. Akhlak yang luhur merupakan dasar tasawuf dan akhlak dalam bentuknya yang paling tinggi adalah buah tasawuf. Akhlak yang utama merupakan semboyan sufi, di antara dasar dan buahnya. Akhlak selalu menyertai seorang sufi. Bukan berarti bahwa akhlak tadi adalah tasawuf. ${ }^{30}$ Tasawuf bukanlah satu-satunya sumber akhlak dalam kehidupan manusia, melainkan hanya salah satu sumber akhlak yang berasal dari ajaran Islam, khususnya bagi ahli tasawuf (sufi).

Akhlak dalam aktivitas yang diajarkan oleh tasawuf untuk mengangkat manusia ke tingkatan shafa al-tauhid. Pada tahap inilah manusia akan memiliki akhlak kepada Allah. Dan manakala seseorang dapat berperilaku dengan perilaku Allah, akan terjadi keselarasan dan keharmonisan antara kehendak manusia dengan Iradah-Nya. Sebagai konsekuensinya, seorang tidak akan mengadakan aktivitas kecuali aktivitas yang positif dan membawa manfaat, serta selaras dengan tuntutan Allah. Menurut al-Ghazali, sebagaiman dikutip M. Amin Syukur, manusia dengan akalnya ibarat pengendara kuda, pergi berburu. Syahwat ibarat kuda, sedang marahnya seperti anjing. Jika pengendali cerdik, kudanya terlatih dan anjingnya terdidik, pasti akan memperoleh kemenangan. Dan sebaliknya apabila ia tidak pandai, kudanya tidak patuh, pasti akan mendapatkan kebinasaan, tidak mungkin memperoleh sesuatu yang dicarinya. Demikian juga, apabila jiwa seseorang bodoh, syahwatnya keras, tidak bisa diarahkan dan nafsu amarahnya tak dapat dikuasai, niscaya akan mendapatkan kesengsaraan dalam hidup ini ${ }^{31}$

Akibat modernisasi dan industrialisasi, manusia mengalami degradasi akhlak yang dapat menjatuhkan harkat dan martabatnya. Kehidupan modern seperti sekarang ini sering menampilkan sifat-sifat yang tidak terpuji, terutama dalam menghadapi materi yang gemerlap ini. Sifat-sifat yang tidak terpuji tersebut adalah hirsh, yaitu keinginan yang berlebih-lebihan terhadapa materi. Dari sifat ini tumbuh perilaku menyimpang,

${ }^{30}$ Abdul Halim Mahmud, Hal Ihwal Tasawuf: Analisa tentang Al-Munqidz Minadh Dhalal (Penyelamat dari Kesesatan) oleh Imam al-Ghzali, terj. Abu Bakar Basymeleh, (Jakarta: Daarul Ihya', 1986), h. 210.

${ }^{31}$ M. Amin Syukur, Metodologi Studi Islam (Semarang: Bima Sakti, 2000), h. 122. 
seperti korupsi dan manipulasi. Sifat kedua ialah al-hasud, yaitu menginginkan agar nikmat orang lain sirna danberalih kepada dirinya. Sifat riya', yaitu sifat suka memamerkan harta atau kebaikan diri dan sebagainya dari berbagai sifat hati ${ }^{32}$

Cara menghilangkan sifat-sifat tersebut ialah dengan mengadakan penghayatan atas keimanan dan ibadahnya, mengadakan latihan secara bersungguh-sungguh, berusaha merubah sifat-sifatnya itu dengan mencari waktu yang tepat. Karena kadangkadang sifat tercela itu muncul dalam keadaan yang tidak tersadari, maka seyogyanya setiap muslim selalu mengadakan introspeksi (muhasabah) terhadap dirinya. Memang diakui bahwa manusia dalam kehidupannya selalu berkompetisi dengan hawa nafsunya yang selalu ingin menguasainya. Agar posisi seseorang berbalik, yakni hawa nafsunya dikuasai oleh akal yang telah mendapat bimbingan wahyu, dalam dunia tasawuf diajarkan berbagai cara, seperti riyadhah (latihan) dan mujahadah (bersungguhsungguh) dalam melawan hawa nafsu tadi. Dengan jalan ini diharapkan seseorang mendapatkan jalan yang diridlai Allah swt. ${ }^{33}$

Dalam struktur maqamat, mengandung beberapa karakteristik dasar yang seharusnya dimiliki oleh seorang sufi. Seorang yang ada pada maqam taubat memiliki kemampuan untuk mengontrol stabilitas nafsunya, menjauhkan nafsu dari kecenderungan jahat dan hanya melakukan yang baik dan bernilai. Seorang yang ada pada maqam wara', secara tegas berupaya meninggalkan hal-hal yang belum jelas guna dan manfaatnya dan hanya memilih sesuatu yang jelas kemanfaatannya. Seorang sufi yang zuhud hanya akan memilih sesuatu berdasarkan pada nilai kemanfaatannya, baik bagi dirinya maupun orang lain. Ia tidak akan terpengaruh pada keindahan kulit luarnya atau kenikmatan yang bersifat sementara, karena seorang zuhud lebih melihat sesuatu dari substansinya. Kebahagiaan dan kepentingan material hanyalah bersifat sementara, karena kebahagiaan yang abadi baginya adalah kebahagiaan yang bersifat spiritual ${ }^{34}$

Dengan demikian zuhud dapat dijadikan benteng untuk membangun diri dari dalam sendiri, terutama dalam menghadapi gemerlapnya materi. Dengan zuhud akan tampil sifat positif lainnya, seperti sifat qana'ah (menerima apa yang telah ada/dimiliki), tawakkal (pasrah diri kepada Allah swt.) dan syukur, yakni menerima nikmat dengan lapang dan mempergunakan sesuai dengan fungsi dan proporsinya.

\section{Pendidikan Akhlak-Sosial}

Tasawuf yang dipraktekkan masa kini harus memperhatikan masalah kemanusiaan dalam kehidupan sosial yang merupakan bagian dari keberagamaan para sufi. Tujuan yang dapat dicapai tetap sama yaitu ketenangan, kedamaian dan kebahagiaan intuitif tetapi kemudian dikembangkan bukan hanya untuk individu melainkan juga dalam bentuk kesalehan sosial.

\footnotetext{
${ }^{32}$ M. Amin Syukur, Menggugat Tasawuf......, h. $114-115$.

${ }^{33}$ M. Amin Syukur, Zuhud di Abad Modern, ......... h. 181.

${ }^{34}$ Hasyim Muhammad, Dialog antara Tasawuf dan Psikologi, Dialog antara Tasawuf dan Psikologi, (Yogyakarta: Pustaka Pelajar, 2001), h. 120
} 
Profil pengamal tasawuf sosial ini tidak semata-mata berakhir pada kesalehan individual melainkan berupaya untuk membangun kesalehan sosial bagi masyarakat di sekitarnya. Mereka tidak hanya memburu surga bagi dirinya sendiri dalam keterasingan, melainkan justru membangun surga untuk orang banyak dalam kehidupan sosial. ${ }^{35}$

M. Amin Syukur berpendapat bahwa dalam pengamalan tasawuf terdapat dua model, yaitu: Pertama, tasawuf yang berorientasi pada perubahan individu atau perubahan internal (internal shift). Di sini individu berusaha untuk membenahi jiwa dan batin. Tasawuf merupakan gerakan dan proses merubah dan menata hati, sehingga dalam diri dan perilaku individu berubah dari berakhlak buruk (akhlak sayyiah) menjadi berakhlak baik (akhlak karimah). Kedua, pada tahap berikutnya perubahan individu ditransformasikan pada aspek sosial. Mulai dari lingkungan terdekat, keluarga dan masyarakat sekitarnya. ${ }^{36}$

Gerakan tasawuf tidak hanya berkutat pada ritual yang bersifat vertikal, namun maju pada garda depan sebagai ritual sosial. Tasawuf membawa visi dan misi transformasi sosial, di mana tasawuf harus mampu menjadi solusi alternatif pemecahan problem-problem sosial untuk menuju era sosial baru. Krisis yang menerpa negeri ini, bukan saja sebatas pada krisis moneter, ekonomi, politik, hukum, sosial dan seterusnya, tetapi berpangkal dan berujung pada krisis akhlak dan spiritual. Jika dirunut krisis tersebut adalah buah dari krisis spiritual keagamaan. Pentingnya esoterisme dalam Islam yakni tasawuf tak bisa dipungkiri. Konsepsi al-Qur'an bahwa dunia ini riil, bukan maya. Beberapa ayat menegaskan agar manusia beriman kepada Allah, hari akhir dan amal shaleh. Ketiga term itu merupakan isyarat sekaligus formulasi yang menyatukan dimensi spiritual yang mengarah pada realitas transedental dan aktifitas kongrit dalam sejarah.

Dengan demikian manusia tidak hanya telah kehilangan wawasan spiritualnya dalam memahami kekuatan-kekuatan alam, melainkan juga tidak mengembangkan kemajuan ilmu pengetahuan dan teknologi modern dengan mengindahkan nilai-nilai akhlak dan spiritual yang bersumber kepada keutuhan dan keseimbangan yang mencerminkan keagungan, keindahan dan kesempurnaan Tuhan yang tidak menghendaki apapun kecuali kebaikan dan kebajikan bagi makhluknya. Jika manusia dalam hatinya selalu dipenuhi dengan nafsu duniawi, selalu menjadikan teknologi modern sebagai sesuatu yang paling berharga. Agar dapat menerima cahaya Tuhan, manusia harus menghilangkan akhlak yang negatif terhadap penggunaan ilmu pengetahuan dan teknologi modern dan mengarahkan yang dikuasainya kepada hal-hal yang konstruktif terhadap kehidupan manusia. Yang diperlukan adalah sikap istiqamah pada setiap masa dan mungkin lebih-lebih lagi diperlukan di zaman modern ini, karena kemodernan bercirikan perubahan. Istiqamah di sini bukan berarti statis, melainkan lebih dekat kepada arti stabilitas yang dinamis. Dapat dikiaskan dengan kendaraan bermotor; semakin tinggi teknologi suatu mobil, semakin mampu dia melaju dengan

\footnotetext{
${ }^{35}$ Abdul Muhayya, Peranan Tasawuf dalam Menanggulangi Krisis Spiritual.... h.126.

${ }^{36}$ Mu'allim, "Dari Kesadaran Spiritual ke Tasawuf Sosial, h. 7.
} 
cepat tanpa guncangan. Maka disebut mobil itu memiliki stabilitas atau istiqamah. Mobil disebut stabil bukanlah pada waktu dia berhenti, tapi justru ketika dia melaju dengan cepat. ${ }^{37}$

Tanggung jawab tasawuf akhlaki bukanlah dengan melarikan diri dari kehidupan dunia nyata, sebagai mana ditujukan oleh sementara orang yang kurang setuju terhadap tasawuf, akan tetapi ia adalah suatu usaha mempersenjatai diri dengan nilai-nilai rohaniah yang baru, yang akan membentengi diri saat menghadapi problema hidup dan kehidupan yang serba meterialistik, dan berusaha merealisasikan keseimbangan jiwa sehingga timbul kemampuan menghadapi beragam problem tersebut dengan sikap optimis.

Nilai-nilai pendidikan akhlak dalam tasawuf akhlaki tersebut, antara lain: Pertama, tasawuf akhlaki merupakan basis yang bersifat fitri pada setiap manusia. Tasawuf merupakan potensi ilahiyah yang ada dalam diri manusia yang berfungsi di antaranya untuk mendesain corak peradaban dunia, sehingga tasawuf dapat mewarnai segala aktivitasnya baik yang berdimensi sosial, politik, ekonomi maupun kebudayaan. Kedua, tasawuf akhlaki bisa berfungsi sebagai alat pengendali dan pengontrol, agar dimensi kemanusiaan tidak ternodai oleh modernisasi yang mengarah pada dekadensi akhlak, kemanusiaan dan keislaman.

Dengan demikian tasawuf akan menghantarkan manusia pada tercapainya "supreme akhlakity" (keunggulan akhlak). Sehingga bisa mencapai insan kamil, mencontoh tokoh sufi ideal dan terbesar dalam sejarah Islam, yakni Nabi Muhammad Saw, karena beliaulah suri-tauladan terbaik bagi seluruh umat manusia, sebagaimana ditegaskan Allah swt. dalam firman-Nya dalam (Q.S. al- Ahzab: 21).

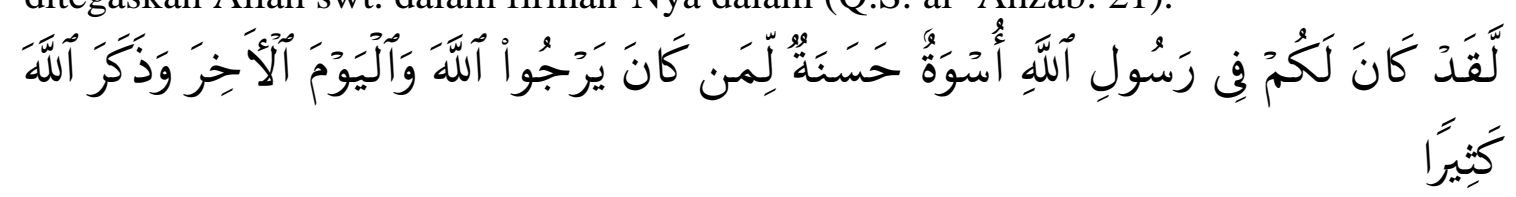

Terjemahnya:

Sesungguhnya telah ada pada (diri) Rasulullah itu suri tauladan yang baik bagimu, (yaitu) bagi orang-orang yang mengharap rahmat Allah dan (kedatangan) hari kiamat dan dia banyak menyebut Allah. ${ }^{38}$

Dengan tasawuf akhlaki, pada dasarnya juga bertujuan sama, di mana pada akhirnya bisa menjadi dan menciptakan rahmat bagi seluruh alam semesta (rahmatan lil-'alamiin). Sebab dalam tasawuf akhlaki terdapat prinsip-prinsip positif yang mampu mengembangkan masa depan manusia, seperti melakukan instrospeksi (muhasabah) baik dalam kaitannya dengan masalah-masalah vertikal maupun horisontal, kemudian meluruskan hal-hal yang kurang baik, selalu berdzikir (dalam arti yang seluas-luasnya)

\footnotetext{
${ }^{37}$ Nurcholish Madjid, Pintu-pintu Menuju Tuhan (Jakarta: Paramadina, 1995), h. 175.

${ }^{38}$ Mohammad Taufiq, Quran in The Word Ver1.2.0, QS/33: 21
} 
kepada Allah swt. sebagai sumber gerak, sumber kenormatifan, sumber motivasi dan sumber nilai yang dapat dijadikan acuan hidup.

Akhlak dalam aktivitas yang diajarkan oleh tasawuf untuk mengangkat manusia ke tingkatan shafa al-tauhid. Pada tahap inilah manusia akan memiliki akhlak kepada Allah. Dan manakala seseorang dapat berperilaku dengan perilaku Allah, akan terjadi keselarasan dan keharmonisan antara kehendak manusia dengan Iradah-Nya. Sebagai konsekuensinya, seorang tidak akan mengadakan aktivitas kecuali aktivitas yang positif dan membawa manfaat, serta selaras dengan tuntutan Allah. Menurut al-Ghazali, sebagaiman dikutip M. Amin Syukur, manusia dengan akalnya ibarat pengendara kuda, pergi berburu. Syahwat ibarat kuda, sedang marahnya seperti anjing. Jika pengendali cerdik, kudanya terlatih dan anjingnya terdidik, pasti akan memperoleh kemenangan. Dan sebaliknya apabila ia tidak pandai, kudanya tidak patuh, pasti akan mendapatkan kebinasaan, tidak mungkin memperoleh sesuatu yang dicarinya. Demikian juga, apabila jiwa seseorang bodoh, syahwatnya keras, tidak bisa diarahkan dan nafsu amarahnya tak dapat dikuasai, niscaya akan mendapatkan kesengsaraan dalam hidup ini. ${ }^{39}$

Al-Ghazali begitu besar perhatiannya, sekaligus usahanya yang tidak pernah berhenti untuk mengarahkan kehidupan manusia yang berakhlak. Hampir seluruh hidupnya ia curahkan untuk berkampanye tentang "gerakan akhlak". Al-Ghazali-lah sebagai pelopor ilmu akhlak dan gerakan akhlak yang bersendikan ajaran relevasi (wahyu). ${ }^{40}$ Pandangan dan pemikirannya mengenai pendidikan akhlak sangat luas dan mendalam sekali, sehingga hampir setiap kitab-kitab yang ditulisnya dalam berbagai bidang, selalu ada hubungannya dengan pelajaran akhlak dan pembentukan budi pekerti manusia.

Akibat modernisasi dan industrialisasi, manusia mengalami degradasi akhlak yang dapat menjatuhkan harkat dan martabatnya. Kehidupan modern seperti sekarang ini sering menampilkan sifat-sifat yang tidak terpuji, terutama dalam menghadapi materi yang gemerlap ini. Sifat-sifat yang tidak terpuji tersebut adalah hirsh, yaitu keinginan yang berlebih-lebihan terhadapa materi. Dari sifat ini tumbuh perilaku menyimpang, seperti korupsi dan manipulasi. Sifat kedua ialah al-hasud, yaitu menginginkan agar nikmat orang lain sirna danberalih kepada dirinya. Sifat riya', yaitu sifat suka memamerkan harta atau kebaikan diri dan sebagainya dari berbagai sifat hati ${ }^{41}$

Cara menghilangkan sifat-sifat tersebut ialah dengan mengadakan penghayatan atas keimanan dan ibadahnya, mengadakan latihan secara bersungguh-sungguh, berusaha merubah sifat-sifatnya itu dengan mencari waktu yang tepat. Karena kadangkadang sifat tercela itu muncul dalam keadaan yang tidak tersadari, maka seyogyanya setiap muslim selalu mengadakan introspeksi (muhasabah) terhadap dirinya. Memang diakui bahwa manusia dalam kehidupannya selalu berkompetisi dengan hawa nafsunya yang selalu ingin menguasainya. Agar posisi seseorang berbalik, yakni hawa nafsunya

\footnotetext{
${ }^{39}$ M. Amin Syukur, Metodologi Studi Islam (Semarang: Bima Sakti, 2000), h. 122.

${ }^{40}$ Zainuddin dkk., Seluk-beluk Pendidikan dari Al-Ghazali (Jakarta: Bumi Aksara, 1991), h. 102

${ }^{41}$ M. Amin Syukur, Menggugat Tasawuf......... h. $114-115$.
} 
dikuasai oleh akal yang telah mendapat bimbingan wahyu, dalam dunia tasawuf diajarkan berbagai cara, seperti riyadhah (latihan) dan mujahadah (bersungguhsungguh) dalam melawan hawa nafsu tadi. Dengan jalan ini diharapkan seseorang mendapatkan jalan yang diridlai Allah swt. ${ }^{42}$

Dalam tasawuf terdapat prinsip-prinsip positif yang mampu menumbuhkan masa depan masyarakat, antara lain hendaknya selalu mengadakan introspeksi (muhasabah), berwawasan hidup moderat, tidak terjerat oleh nafsu rendah, sehingga lupa pada diri dan Tuhannya. Dalam menempuh jenjang kesempurnaan rohani, dikenal tahapan: takhalli, tahalli dan tajalli. Takhalli (membersihkan sifat-sifat tercela) seperti hasud (dengki), takabbur (sombong), tama' (keinginan terhadap sesuatu), hirs (keinginan yang belebihlebihan terhadap sesuatu), riya' (pamer kebaikan), sum'ah (ingin didengar orang), 'ujub (bangga diri) dan sebagainya. Takhalli sebagai langkah awal menuju manusia yang berkepribadian utuh itu dilengkapi dengan sikap terbuka. Artinya, orang yang bersangkutan menyadari betapa buruknya sifat-sifat yang ada pada dirinya, kemudiantimbul kesadaran untuk memberantas dan menghilangkan. Apabila hal ini bisa dilakukan dengan sukses, maka akan tampil pribadi yang bersih dari sifat madzmumah. Jenjang kedua ialah tahalli, yakni menghiasi diri dengan sifat-sifat terpuji dan akhlak karimah. Untuk membangun benteng dalam diri masing-masing individu, terutama dalam menghadapi gemerlapnya materi ini perlu di bangun dan diperkokoh sifat qana'ah, tawakkal, zuhud, wara', sabar, syukur dan sebagainya. Tahalli merupakan pengungkapan secara progresif nilai akhlak yang terdapat dalam Islam.

Dalam struktur maqamat, mengandung beberapa karakteristik dasar yang seharusnya dimiliki oleh seorang sufi. Seorang yang ada pada maqam taubat memiliki kemampuan untuk mengontrol stabilitas nafsunya, menjauhkan nafsu dari kecenderungan jahat dan hanya melakukan yang baik dan bernilai. Seorang yang ada pada maqam wara', secara tegas berupaya meninggalkan hal-hal yang belum jelas guna dan manfaatnya dan hanya memilih sesuatu yang jelas kemanfaatannya. Seorang sufi yang zuhud hanya akan memilih sesuatu berdasarkan pada nilai kemanfaatannya, baik bagi dirinya maupun orang lain. Ia tidak akan terpengaruh pada keindahan kulit luarnya atau kenikmatan yang bersifat sementara, karena seorang zuhud lebih melihat sesuatu dari substansinya. Kebahagiaan dan kepentingan material hanyalah bersifat sementara, karena kebahagiaan yang abadi baginya adalah kebahagiaan yang bersifat spiritual ${ }^{43}$

Bagaimana zuhud sebagai upaya pembentukan akhlak terhadap dunia di masa modern seperti ini. Untuk mengungkap hal ini, maka perlu mencermati bagaimana sesungguhnya masyarakat modern itu. Dengan demikian alam dapat ditaklukkan, manusia merasa lebih leluasa bahkan merasa lebih berkuasa. Ketiga, tumbuhnya berpikir rasional, sebagian besar kehidupan umat manusia ini semakin diatur oleh aturan-aturan rasional. Keempat, tumbuhnya sikap hidup yang materialistik, artinya

\footnotetext{
${ }^{42}$ M. Amin Syukur, Zuhud di Abad Modern, ........ h. 181.

43 Hasyim Muhammad, Dialog antara Tasawuf dan Psikologi, Dialog antara Tasawuf dan Psikologi, (Yogyakarta: Pustaka Pelajar, 2001), h. 120
} 
semua hal diukur oleh nilai kebendaan dan ekonomi. Kelima, meningkatnya laju urbanisasi. ${ }^{44}$ Hossein Nasr menyatakan bahwa akibat masyarakat modern yang memiliki ciri tersebut di atas, maka ia berada dalam wilayah pinggiran eksistensinya sendiri, bergerak menjauhi pusat, sementara pemahaman agama yang berdasarkan wahyu mereka tinggalkan dan hidup dalam keadaan sekuler. ${ }^{45}$

Dalam kaitannya dengan problema masyarakat modern, maka secara praktis tasawuf mempunyai potensi besar karena mampu menawarkan pembebasan spiritual, tasawuf mengajak manusia mengenal dirinya sendiri, dan akhirnya mengenal Tuhannya. Tasawuf dapat memberi jawaban-jawaban terhadap kebutuhan spiritual mereka akibat pendewaan mereka terhadap selain Tuhan, seperti materi dan sebagainya. Memang diakui bahwa manusia dalam kehidupannya selalu berkompetensi dengan hawa nafsu yang selalu ingin menguasainya. Agar posisi seseorang dapat terbalik, yakni hawa nafsunya dikuasai oleh akal yang telah mendapatkan bimbingan wahyu, dalam dunia tasawuf diajarkan berbagai terapi, seperti riyādah (latihan) dan Mujāhadah (bersungguh-sungguh) dalam melawan hawa nafsu tadi. ${ }^{46}$

Setelah seseorang telah mampu menguasai dirinya, dapat menanamkan sifat-sifat terpuji dalam jiwanya, maka sudah barang tentu hatinya menjadi jernih, ketenangan dan ketenteraman memancar dari hatinya. Inilah hasil yang dicapai seseorang dalam tasawuf yang disebut dengan tajallī, yaitu sampai pada nūr Ilāhī dalam hatinya. ${ }^{47}$ Dalam keadaan yang demikian ini, seseorang bisa membedakan mana yang baik dan yang tidak baik, mana yang batil dan mana yang haq. Tajallī sebagai kristalisasi nilai-nilai religio akhlak dalam diri manusia yang berarti melembaganya nilai-nilai Ilahiyah yang selanjutnya akan merefleksikan dalam setiap gerak dan aktivitasnya. Pada tingkatan ini seseorang telah mencapai tingkat kesempurnaan ("insan kämil"). Dia dapat merealisasikan segala kemungkinan yang dapat dicapai oleh makhluk manusia yang membawa potensi keilahian. $^{48}$

Capaian terakhir ini merupakan puncak kebahagiaan seorang sufi. Orang seperti ini akan mencapai tuma'n inah al-qalb, ketenangan hati yang merupakan pangkal kebahagiaan seseorang, baik bahagia di dunia maupun di akhirat. Orang yang demikian ini hidupnya penuh dengan optimisme (raja'), tidak mungkin tergoda oleh situasi dan kondisi yang melingkupinya, bisa menguasai diri dan menyesuaikan diri di tengahtengah deru modernisasi dan industrialisasi. Oleh karena itu kalau kehidupan manusia tidak menginginkan adanya ketimpangan sosial yang menitikberatkan pada kepuasan materialitas dan mengabaikan nilai-nilai spiritual, maka zuhud harus menjadi gerakan

\footnotetext{
${ }^{44}$ Atho' Mudzhar, Guru Pendidikan Agama Islam dalam Perpektif Tantangan Hidup Beragama di Masa Depan. Semarang : IAIN Walisongo, 1993), h.4

${ }^{45}$ Komarudin Hidayat, Upaya Pembebasan manusia : Tinjauan Sufistik terhadap Manusia Modern menurut Hossein Nasr, dalam M. Dawam Rahadjo (ed.), Insan Kamil. Jakarta: Grafida Pers, 1985), h.184

${ }^{46}$ Amin Syukur, Zuhud di Abad Modern, h. 181

${ }^{47}$ Amin Syukur, Zuhud di Abad Modern, h. 183

${ }^{48}$ Amin Syukur, Zuhud di Abad Modern, h. 183
} 
akhlak, yang pada akhirnya dapat mengantarkan manusia menuju kebaikan dan kebenaran, sehingga tidak terjadi lagi adanya krisis akhlak dan krisis kepercayaan seperti yang terjadi pada masa sekarang ini.

\section{KESIMPULAN}

1. Tasawuf pada hakekatnya adalah dimensi terdalam dan esoteris dari Islam (the inner and esoteric dimension of Islam ) yang bersumber dari al-Qur'an dan alHadis. Adapun syari'ah adalah dimensi luar atau eksoteris ajaran Islam. Pengamalan kedua dimensi itu secara seimbang merupakan keharusan dari setiap muslim, agar di dalam mendekatkan diri kepada Allah menjadi sempurna lahir dan batin

2. Problema masyarakat modern, secara praktis tasawuf mempunyai potensi besar karena mampu menawarkan pembebasan spiritual, tasawuf mengajak manusia mengenal dirinya sendiri, dan akhirnya mengenal Tuhannya. Tasawuf dapat memberi jawaban-jawaban terhadap kebutuhan spiritual mereka akibat pendewaan mereka terhadap selain Tuhan, seperti materi dan sebagainya.

3. Konsep paham tasawuf yang tetap mempertahankan esensi awal dari tasawuf, yaitu akhlak. Itu sebabnya dapat disebut 'tasawuf akhlaki'. Perlu ditegaskan di sini, mengapa "akhlak" disebut esensi awal dari tasawuf, karena arahnya adalah melaksanakan hidup "sederhana" dan sikap hidup ini pada akhirnya membuahkan tindakan akhlak. Tasawuf membawa visi dan misi transformasi sosial, di mana tasawuf harus mampu menjadi solusi alternatif pemecahan problem-problem sosial untuk menuju era sosial baru.

\section{DAFTAR PUSTAKA}

Abdul Muhayya, "Peranan Tasawuf dalam Menanggulangi Krisis Spiritual", dalam M. Amin Syukur dan Abdul Muhayya', (eds.), Tasawuf dan Krisis, Yogyakarta: Pustaka Pelajar, 2001

Abdullah, M. Yasin, Studi Akhlak dalam Persfektif al-Qur"an, Cet, I; Jakarta: Amzah, 2007

Aceh, Abu Bakar, Pengantar Sejarah Sufi dan Tasawuf, Cet.VII; Solo:Ramadhani, 1993.

al-Ghanimi, Abu al-Wafa', Sufi dari Zaman ke Zaman, pen., Ahmad Rofi' Utsmani, Bandung: Pustaka, 1985.

Ali, Mukti, Agama, Moralitas dan Perkembangan Kontemporer dalam, Mukti Ali dkk, Agama dalam Pergaulan Masyarakat Kontemporer, Cet. I; Yogyakarta: Tiara Wacana Yogya, 1998

al-Tusi, Abu Nasr al-Sarraj, Al-Luma', Mesir: Dar al- Kutub al-Hadithah, 1960.

Anwar, Rosyid, Solihin, , Akhlak Tasawuf, Manusia, Etika, dan Makna Hidup, Cet. I; Bandung: Nuansa, 2005. 
Aqib, Kharisuddin, An-Nafs: Psiko-Sufistik Pendidikan Islami, Nganjuk: Ulul Albab Press, 2009

At-Taftazani, dalam Syamsun Ni'am, The Wisdom Of KH Achmad Siddiq: Membumikan Tasawuf, Surabaya: Erlangga, 2006.

Bakhtiar, Laleh, Sufi: Expressions Of The Mystic Quest, terj. Purwanto, Perjalanan Menuju Tuhan, Dari Maqam-Maqam hingga Karya Besar Dunia Sufi, Bandung: Yayasan Nuansa Cendekia, 2001.

Ghazali, Imam, Ringkasan Ihya Ulumuddin, Jakarta: Akbar Media Eka Sarana, 2008.

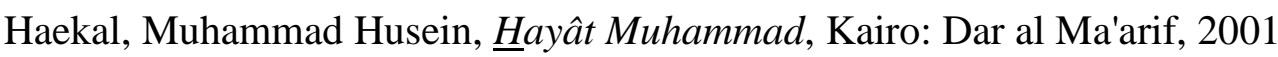

Haeri, Fadhlalla. Dasar-Dasar Tasawuf. Pustaka Sufi. Yogyakarta : 2003.

Halim, Abdul Mahmud, Tasawuf di Dunia Islam, Penerbit, Pustaka Setia, Jakarta, 2002

Hamdan, Rasyid, Sufi Berdasi, Mencapai Derajat Sufi dalam Kehidupan Modern, Jakarta: Al-Mawardi, 2006

Hamka, Tasawuf Modern, Penerbit Pustaka Panjimas, Jakarta, 2005 , Perkembangan Tasawuf dari Abad ke Abad, Cet. IV; 1906) dalam M Zain Abdullah, Dzikir dan Tasawuf, Solo: Qaula, 2007.

......., Prinsip Dan Kebijaksanaan Dakwah Islam, Jakarta: Pustaka Panji Mas, 1980.

Harahap, Syahrin, Islam dan Implementasi Pemberdayaan, Cet. I; Yogyakarta: PT. Tiara Wacana Yogyakarta, 1999

Kahmad, Dadang, Tarekat dalam Islam: Spiritualitas Masyarakat Modern, Bandung: Pustaka Setia, 2002.

Kartanegara, Mulyadi, Menyelami lubuk Tasawuf, Jakarta: Erlangga, 2006.

Khasanah, Siti Uswatun, Berdakwah Dengan Jalan Debat: antara muslim dan non muslim, Purwokerto: STAIN Press, 2007.

Muhammad, Hasyim, Dialog antara Tasawuf dan Psikologi, Dialog antara Tasawuf dan Psikologi, Yogyakarta: Pustaka Pelajar, 2001

Muhammad, Yusuf Khathar, al-Mausu'ah al-Yusufiyah fî bayâni adillah al-Sufiyah, Dar el-Taqwâ, Damascus,tt.

Nasution, Harun, Falsafah dan Mistisisme dalam Islam, Jakarta: Bulan Bintang, 1990.

Rasyid, Hamdan, Sufi Berdasi, Mencapai Derajat Sufi dalam Kehidupan Modern, AlMawardi, Jakarta, 2006

Rogers, Everett M. Communication Technology, The New Media in Society.London: The Free Press Collier Macmillan Publisher. 1986

Salim, Peter dan Yenny Salim.. Kamus Bahasa Indonesia Kontemporer. Jakarta: Modern English. 1999

Sardar, Ziauddin, Information and The Muslim World: A Strategy for The Twenty-First Century, diterjemahkan oleh Priyono dengan judul Tantangan Dunia Islam Abad 21 Menjangkau Informasi, Cet. VII; Bandung: Mizan, 1996.

Seyyed Hossein Nasr, dkk, Warisan Sufi, Sufisme Klasik dari Permulaan hingga Rumi (700-1300 M), Jogjakarta, Pustaka Sufi 2002. 
Siregar, Rivay, Tasawuf : Dari Sufisme Klasik ke Neo-Sufisme, Jakarta: RajaGrafindo, 2002

Siroj, Said Agil, Tasawuf sebagai kritik Sosial: Mengedepankan Islam sebagai Inspirasi bukan Aspirasi, Bandung: Mizan, 2006.

Siti Muriah, Metodologi Dakwah Kontemporer, Yogyakarta: Mitra Pustaka, 2000.

Solihin, Melacak Pemikiran Tasawuf di Nusantara, Rajawali Pers, Jakarta, 2005

Syukur, Amin, Menggugat Tasawuf: Sufisme dan Tanggung Jawab Sosial Abad 21, Yogyakarta:Pustaka pelajar, 1999.

Metodologi Studi Islam, Semarang: Bima Sakti, 2000

Zuhud di Abad Modern, Yogyakarta: Pustaka Pelajar, 1997

Zahri , Mustafa, Kunci Memahami Ilmu Tasawuf, Surabaya: Bina Ilmu, 1995. 